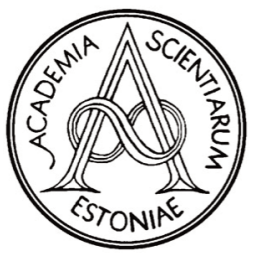

Proceedings of the Estonian Academy of Sciences, 2021, 70, 1, 40-50

https://doi.org/10.3176/proc.2021.1.01

Available online at www.eap.ee/proceedings

CHEMISTRY

\title{
Chemical constituents and biological activities of Balanophora fungosa varietas globosa growing in Vietnam, as well as comparative chromatography with some species of the genus Balanophora J. R. \& G. Forst
}

\author{
Nguyen Thanh Tung ${ }^{\mathrm{a}}$, Nguyen Quang Hung ${ }^{\mathrm{b}}$, Nguyen Thi Luyen $^{\mathrm{b}}$, Nguyen Tien Dat $^{\mathrm{b}}$, \\ Tõnu Püssa ${ }^{c}$, Linda Rusalepp ${ }^{c}$, Mihkel Ilisson ${ }^{\mathrm{d}}$ and Ain Raale*
}

\author{
a Department of Pharmacognosy, Hanoi University of Pharmacy, Le Thanh Tong 15, 100000 Ha Noi, Vietnam \\ ${ }^{\mathrm{b}}$ Vietnam Academy of Science and Technology, Hoang Quoc Viet 18, 100000 Ha Noi, Vietnam \\ ${ }^{c}$ Department of Food Hygiene, Estonian University of Life Sciences, Kreutzwaldi 56/3, 51014 Tartu, Estonia \\ ${ }^{\mathrm{d}}$ Chair of Analytical Chemistry, Institute of Chemistry, Faculty of Science and Technology, University of Tartu, Ravila 14A, \\ 50411 Tartu, Estonia \\ ${ }^{\mathrm{e}}$ Institute of Pharmacy, Faculty of Medicine, University of Tartu, Nooruse 1, 50411 Tartu, Estonia
}

Received 6 July 2020, accepted 13 October 2020, available online 18 January 2021

(C) 2021 Authors. This is an Open Access article distributed under the terms and conditions of the Creative Commons AttributionNonCommercial 4.0 International License (http://creativecommons.org/licenses/by-nc/4.0/).

\begin{abstract}
The chemical composition and biological activities of Balanophora fungosa var. globosa (BFG) were studied for the first time. Also, the chemical composition of some other Balanophora species was established for comparison. Phenolic compounds isolariciresinol, gallic acid, pinoresinol, methyl caffeate, and epipinoresinol-4-O- $\beta$-D-glucopyranoside were isolated from Balanophora fungosa var. globosa collected in Vietnam and identified by the NMR analysis. Some in vitro biological activities of the isolated compounds, including the inhibitory effect on NO production and cytotoxic effects, were evaluated. The chromatographic methods were developed to determine the chemical fingerprints of BFG and its very close taxon subsp. indica (Arn.) B. Hansen (BFI), also of the two new species recently recorded for the flora of Vietnam Balanophora tobiracola Makino (BT) and Balanophora subcupularis P.C. Tam (BS). Among the isolated compounds, isolariciresinol showed a moderate inhibitory effect on NO production $(\mathrm{I} \%=56.02$ at concentration of $100 \mu \mathrm{g} / \mathrm{mL})$, while gallic acid at concentration of $100 \mu \mathrm{g} / \mathrm{mL}$ demonstrated moderate cytotoxicity against cancer cell lines MCF-7 (human breast carcinoma) and PC3 (human prostate gland carcinoma). The HPTLC analysis showed similarities in the chemical compositions of BFG and BFI, as well as the difference between their compositions and these of BT and BS. $O$-caffeoyl- $O$-galloyl-glucoside I, caffeic acid glucoside, $O$-caffeoyl-di-galloyl- $\beta$-D-glucoside V, and 1- $O$-caffeoyl-3- $O$-galloyl4,6-HHDP- $\beta$-D-glucoside as principal compounds were identified among 31 phenolic substances of BFI and BFG by using HPLC-MS/MS.
\end{abstract}

Key words: anti-cancer activity, anti-inflammatory activity, Balanophora fungosa subsp. indica, Balanophora subcupularis, Balanophora tobiracola, isolation.

\section{INTRODUCTION}

Balanophora fungosa var. globosa (Jungh.) B. Hansen (BFG) (Fig. 1a), with the Vietnamese name Dó đất sần (Balanophoraceae) is a dioecious parasitic plant, recorded

\footnotetext{
* Corresponding author, ain.raal@ut.ee
}

by B. Hansen as an endemic species of Java (Indonesia) and distributed in Java only (Hansen, 1972). Later B. fungosa var. globosa was recorded in the Checklist of plant species of Vietnam (Ban, 2005) and is one of the two taxa of $B$. fungosa in Vietnam, along with $B$. fungosa subsp. indica (BFI) (Fig. 1b). Of these two taxa, BFI has been used in Vietnamese folk medicine to treat some 
(a)

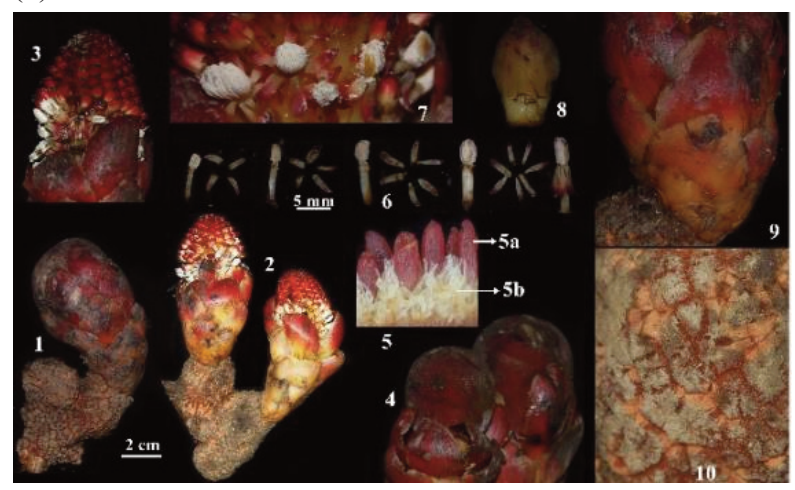

B. fungosa var. globosa 1,4. Plant with female inflorescence; 2,3. Plant with male inflorescence; 5 . Female flowers $(5 b)$ and spadicles (5a); 6,7. Male flowers; 8,9. Leaves; 10 . Surface of rhizome.

(c)

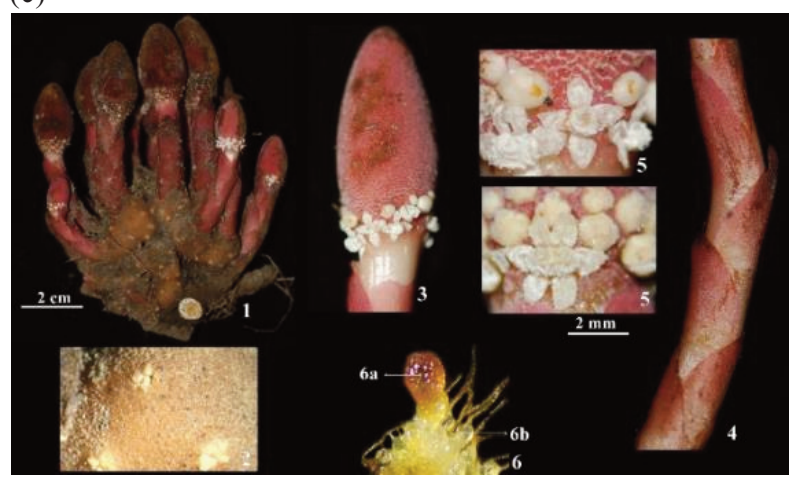

B. subcupularis 1. Plant with androgynous inflorescences; 2. Surface of rhizome; 3 . Inflorescence; 4. Scape with leaves; 5. Male flowers; 6 . Female flowers (6b) and spadicle (6a). (b)

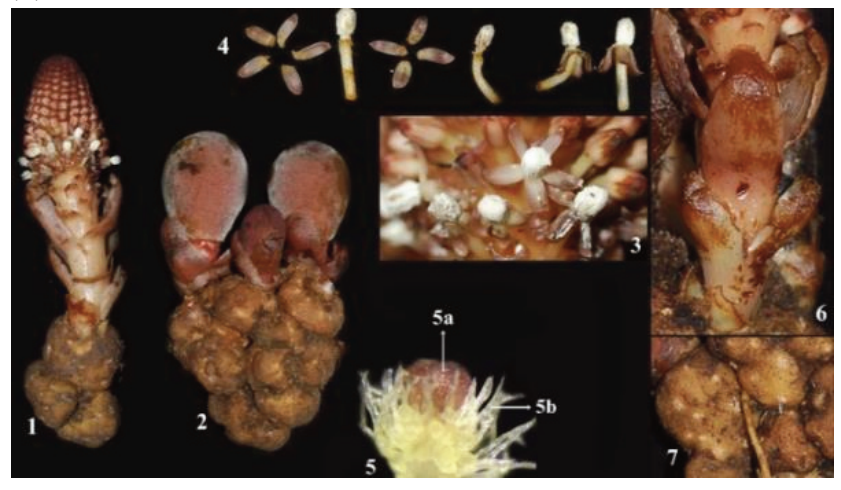

B. fungosa subsp. indica 1. Plant with male inflorescence; 2. Plant with female inflorescence; 3,4. Male flowers, 5. Female flowers (5b) and spadicle (5a); 6. Leaves; 7. Surface of rhizome.

(d)

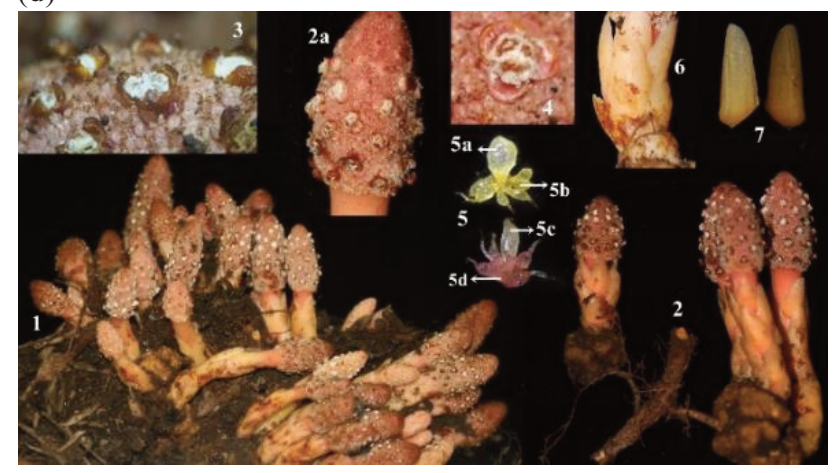

B. tobiracola 1,2. Plant with androgynous inflorescence (2a); 3 . Surface of inflorescence; 4. Male flower, 5. Female flowers (5b, 5d) and spadicles (5a, 5c); 6. Scape with leaves; 7. Leaves.

Fig. 1. Morphological characteristics of some Balanophora species.

diseases, such as abdominal pain and body aches, as well as to be soaked in wine to produce a drink which could help strengthen muscles and bones (Vo, 2012). Recently, Balanophora subcupularis P.C. Tam (BS) (Fig. 1c) and Balanophora tobiracola Makino (BT) (Fig. 1d) were recorded in the flora of Vietnam.

Phytochemical investigation of species belonging to the genus Balanophora resulted in the isolation and identification of various types of compounds, including hydrolysable tannins, phenolic acids, simple phenylpropanoids, lignans, coumarins, and triterpenes (Hou et al., 2009; Wang et al., 2012). There are only a few publications describing chemical constituents of B. fungosa (Panthama et al., 2009; Zhou et al., 2019). Some hydrolysable tannins, phenolic acids (gallic acid, ellagic acid), phenylpropanoids (caffeic acid, methyl coniferin, butyl coniferin, brevifolin), pentacyclic triterpenoids (balanophorin A, balanophorin B, monogynol A 3-palmitat, $\beta$-amyrin, $\beta$-amyrin acetate, $\beta$-amyrin stearate and $\beta$-amyron) and sterols (daucosterol and $\beta$-sitosterol) were isolated from BFI in China (Dai et al., 2005; Fang et al., 2018). Lately, three new muurolene-type sesquiterpene glycosides were isolated from the whole plants of BFI (Bui et al., 2019). The chemical investigation of B. tobiracola Makino led to the isolation of six phenylpropanoids ( $p$ methoxycinnamic acid, trans-cinnamic acid, caffeic acid methyl ester, p-coumaric acid, m-coumaric acid, caffeic acid), two triterpenes ( $\beta$-amyrin acetate, lupeol), two dihydrochalcones (3-hydroxyphloretin, 3-hydroxyphloretin 4'- $\beta$-D-glucoside) (Ito et al., 1980), as well as galloyl, caffeoyl and hexahydroxydiphenoyl esters of 3-hydroxyphloretin 4'- $\beta$-D-glucoside (Tanaka et al., 2005). The ethyl acetate fractions of BT and BS showed significant xanthine oxidase $(\mathrm{XO})$ inhibitory activity with $\mathrm{IC}_{50}$ values of 11.87 and $48.41 \mu \mathrm{g} / \mathrm{mL}$ (Tung et al., 2019). Nevertheless, literature survey indicated lack of published data about the chemical compositions of BFG and BS, although these species have 
been used in folk medicine by the local people for a long time.

The aim of this study was the development of HPTLC and HPLC-MS/MS methods to compare the chemical compositions of the aforesaid species, as well as isolation and identification of some compounds from BFG for the first time, along with studying their biological activities.

\section{MATERIALS AND METHODS}

\subsection{Plant material}

Whole plants of Balanophora fungosa var. globosa (Jungh.) B. Hansen (BFG) (12 kg), B. fungosa subsp. indica (Arn.) B. Hansen (BFI) (10 kg), B. subcupularis P.C. Tam (BS) (4 kg), and B. tobiracola Makino (BT) (3 kg) were collected (Table 1). The plants were identified by Prof. Phan Ke Loc and MSc Nguyen Anh Duc, Faculty of Biology, VNU University of Science, Vietnam National University, Hanoi, Vietnam (Fig. 1). The voucher specimens (VS) were deposited at the Faculty of Biology, VNU University of Science, Vietnam National University, Hanoi, Vietnam. The plant materials were dried in a ventilated oven and stored in sealed polyethylene bags until analysis.

\subsection{Extraction and isolation}

The air-dried and powdered whole plant of BFG $(3.4 \mathrm{~kg})$ was extracted with methanol (10 litres $\times 3$ times) in a sonic bath for $30 \mathrm{~min}$. The combined extracts were concentrated in vacuo to obtain a crude residue $(550 \mathrm{~g})$. This crude extract was suspended in water and successively partitioned between $n$-hexane and ethyl acetate to obtain residues from $n$-hexane phase (22.38 g) and ethyl acetate phase (274 g), respectively. The water fraction was evaporated to obtain water-soluble residue.

NMR $\left({ }^{1} \mathrm{H}\right.$ and $\left.{ }^{13} \mathrm{C}\right)$ spectra of the isolated compounds were recorded by a Bruker Avance III HD spectrometer. ${ }^{1} \mathrm{H}$ and ${ }^{13} \mathrm{C}$ spectra were measured at $700 \mathrm{MHz}$ and $176 \mathrm{MHz}$ correspondingly. DMSO- $d_{6}$, methanol- $d_{4}$ and acetone- $d_{6}$ were utilized as solvents and their residual peaks (DMSO- $d_{6}$ : $2.50 \mathrm{ppm}$ for ${ }^{1} \mathrm{H}$ and $39.52 \mathrm{ppm}$ for ${ }^{13} \mathrm{C}$; methanol- $d_{4}$ : $3.31 \mathrm{ppm}$ for ${ }^{1} \mathrm{H}$; acetone- $d_{6}: 2.05$ ppm for ${ }^{1} \mathrm{H}$ and $29.84 \mathrm{ppm}$ for ${ }^{13} \mathrm{C}$ ) were used for spectrum calibration. Structural assignments were performed by comparing the spectra with literature data.

\subsection{Bioassays}

\subsubsection{NO production in LPS-stimulated RAW264.7 cells}

The inhibitory effect of the isolated compounds on the NO production in LPS-stimulated RAW 264.7 cells (Table 1) was evaluated by using the above described method (Dat et al., 2012). RAW 264.7 cells were cultured in DMEM, supplemented with $10 \%$ (v/v) FBS, penicillin and streptomycin sulphate with the conditions maintained in a humidified $5 \% \mathrm{CO}_{2}$ and atmosphere at $37{ }^{\circ} \mathrm{C}$. After that, these cells were seeded in a 96-well plate at $2.5 \times 10^{5}$ cells/well. The cells were treated with different concentrations of samples prepared in DMSO, followed by incubation for further $24 \mathrm{~h}$. Nitrite concentration in the culture supernatant was estimated by the Griess method, in which $100 \mu \mathrm{L}$ of the cultured supernatant was transferred to another 96-well plate before adding $100 \mu \mathrm{L}$ of Griess reagent. The absorbance of the reaction solution was measured at $570 \mathrm{~nm}$ with a microplate reader. In addition, the remaining cell solutions in a 96 -well plate were evaluated by measuring cell viability with 3-(4,5-dimethylthiazole-2-yl)-2,5-diphenyl tetrazolium bromide (MTT) assay. Cardamonin (SigmaAldrich, St. Louis, Missouri, USA) was used as a

Table 1. Information of Balanophora species

\begin{tabular}{|c|c|c|c|c|}
\hline Id & Scientific names & Collecting time \& location & $\begin{array}{l}\text { Geographic } \\
\text { coordinator }\end{array}$ & Number of VS \\
\hline BFG & $\begin{array}{l}\text { Balanophora fungosa } \\
\text { var. globosa (Jungh.) } \\
\text { B. Hansen }\end{array}$ & $\begin{array}{l}\text { Bidoup-Nuiba National Park, } \\
\text { Lam Dong province; } \\
\text { January } 2016\end{array}$ & $\begin{array}{l}12^{\circ} 05^{\prime} 23^{\prime \prime} \mathrm{N} \\
108^{\circ} 27^{\prime} 10^{\prime \prime} \mathrm{E}\end{array}$ & HNU 024066 \\
\hline BFI & $\begin{array}{l}\text { B. fungosa subsp. Indica } \\
\text { (Arn.) B. Hansen }\end{array}$ & $\begin{array}{l}\text { Sapa city, Lao Cai province; } \\
\text { January } 2017\end{array}$ & $\begin{array}{l}22^{\circ} 19^{\prime} 35^{\prime \prime} \mathrm{N} \\
103^{\circ} 48^{\prime} 21^{\prime \prime} \mathrm{E}\end{array}$ & HNU 024069 \\
\hline BS & B. subcupularis P.C. Tam & $\begin{array}{c}\text { Muong Lay district, Dien Bien } \\
\text { province; November } 2017\end{array}$ & $\begin{array}{l}22^{\circ} 03^{\prime} 56^{\prime \prime} \mathrm{N} \\
103^{\circ} 06^{\prime} 13^{\prime \prime} \mathrm{E}\end{array}$ & HNU 024068 \\
\hline BT & B. tobiracola Makino & $\begin{array}{l}\text { Bac Son district, Lang Son } \\
\text { province; January } 2018\end{array}$ & $\begin{array}{l}21^{\circ} 53^{\prime} 33^{\prime \prime} \mathrm{N} \\
106^{\circ} 22^{\prime} 57^{\prime \prime} \mathrm{E}\end{array}$ & HNU 024056 \\
\hline
\end{tabular}


positive control. The inhibitory activity was calculated by the following formula:

$$
\mathrm{I} \%=\frac{\mathrm{OD}(\text { sample })-\mathrm{OD}(\text { blank })}{\text { OD }(\text { LPS })-\text { OD }(\text { blank })} \times 100 .
$$

The remaining cell solutions in the cultured 96-well plate were evaluated by measuring cell viability with the MTT assay.

\subsubsection{Cytotoxic assays}

Cytotoxicity of the isolated compounds (Table 2) against the four cancer cell lines MCF-7, A549, Hep3B, PC3 was estimated by a method described in literature, using MTT cell proliferation assay kits (Scudiere et al., 1988). The cells were cultured in RPMI-1640 or DMEM, supplemented with $10 \%$ FBS, penicillin (100 units $/ \mathrm{mL}$ ) and streptomycin sulphate $(100 \mu \mathrm{g} / \mathrm{mL})$ at $37{ }^{\circ} \mathrm{C}$ with $5 \% \mathrm{CO}_{2}$. Briefly, cells were seeded $\left(1 \times 10^{5}\right.$ cells/well, in triplicate $)$ in a 96-well flat-bottom plate and incubated overnight. After $24 \mathrm{~h}$, DMSO solutions of the isolated compounds in different concentrations were added to the cells. The treated cells were incubated for $48 \mathrm{~h}$ at $37^{\circ} \mathrm{C}$, followed by the MTT assay according to the manufacturer's guidelines. The absorbance (OD; $\lambda=570 \mathrm{~nm}$ ) was recorded and a nonlinear regression analysis was performed in Excel software to determine the cell survival. In this bioassay, camptothecin (Sigma-Aldrich, St. Louis, Missouri, USA) was used as a positive control:

$$
\% \text { Cell survival }(C S \%)=\frac{A s-A b}{A c-A b} \times 100 .
$$

[As: Absorbance of sample; $A b$ : Absorbance of blank; $A c$ : Absorbance of control].

\subsection{HPTLC and HPLC-MS/MS analyses}

Powdered plant materials (2 g) were extracted with methanol $(5 \mathrm{~mL} \times 10 \mathrm{~min} \times 3$ times $)$ by sonication. After filtration through a cotton filter, the filtrate was combined and the solvent was evaporated to obtain solid residue, which was kept in refrigerator $\left(2-4^{\circ} \mathrm{C}\right)$. Before the HPLC analysis, methanol $(10 \mathrm{~mL})$ was used to dissolve the residue. After centrifugation at a cooling centrifuge Eppendorf 510R, the supernatants were analysed and stored at $-20{ }^{\circ} \mathrm{C}$.

\subsubsection{HPTLC analysis}

The HPTLC analyses were performed by means of a HPTLC system including the Applicator CAMAG Linomat 5, the Auto Developing Chamber (ADC-2) and the TLC Visualizer. The same volume $(10 \mu \mathrm{L})$ of the

\begin{tabular}{|c|c|c|c|c|c|}
\hline Samples & Concentration $(\mu \mathrm{g} / \mathrm{mL}$ & $\%$ Inhibitory & $\pm \mathrm{SD}$ & $\begin{array}{c}\% \text { Cell } \\
\text { survival }\end{array}$ & $\pm \mathrm{SD}$ \\
\hline \multirow[t]{2}{*}{1} & 30 & 39.78 & 0.52 & 85.02 & 1.34 \\
\hline & 100 & 56.02 & 0.90 & 71.19 & 0.53 \\
\hline \multirow[t]{2}{*}{2} & 30 & 13.73 & 0.38 & 75.70 & 0.04 \\
\hline & 100 & 19.61 & 0.76 & 55.83 & 1.72 \\
\hline \multirow[t]{2}{*}{3} & 30 & 28.29 & 0.90 & 74.48 & 0.42 \\
\hline & 100 & 45.38 & 0.63 & 69.61 & 0.30 \\
\hline \multirow[t]{2}{*}{4} & 30 & 27.45 & 0.43 & 70.70 & 2.07 \\
\hline & 100 & 30.25 & 0.29 & 63.42 & 0.21 \\
\hline \multirow[t]{2}{*}{5} & 30 & 33.61 & 1.01 & 79.87 & 0.87 \\
\hline & 100 & 36.41 & 0.63 & 66.40 & 2.07 \\
\hline \multirow[t]{2}{*}{ Cardamonin* } & $0.3 \mu \mathrm{M}$ & 30.25 & 0.38 & 91.45 & 0.33 \\
\hline & $3 \mu \mathrm{M}$ & 79.83 & 1.01 & 82.96 & 1.37 \\
\hline
\end{tabular}

Table 2. Inhibitory effect of the isolated compounds on NO production

* Positive control. 
methanol extracts of $B$. fungosa var. globosa, $B$. fungosa subsp. indica, B. tobiracola and B. subcupularis was applied on the silica gel $60 \mathrm{~F}_{254} \mathrm{HPTLC}$ plate $(10 \mathrm{~cm} \times 10 \mathrm{~cm})$ while the volume of the isolated compound solutions was $5 \mu \mathrm{L}$. The HPTLC was developed on the basis of two eluent systems. After development and derivatization with compatible reagents, images of the plates were taken and documented by the TLC Visualizer. The chromatographic evaluations were performed with visionCATs software (Figs 2 and 3).

\subsubsection{HPLC-MS/MS analysis}

The liquid chromatographic analysis of the extracts was carried out by a 1290 Infinity system (Agilent Technologies, Waldbronn, Germany) coupled to an Agilent 6450 Q-TOF mass spectrometer equipped with a
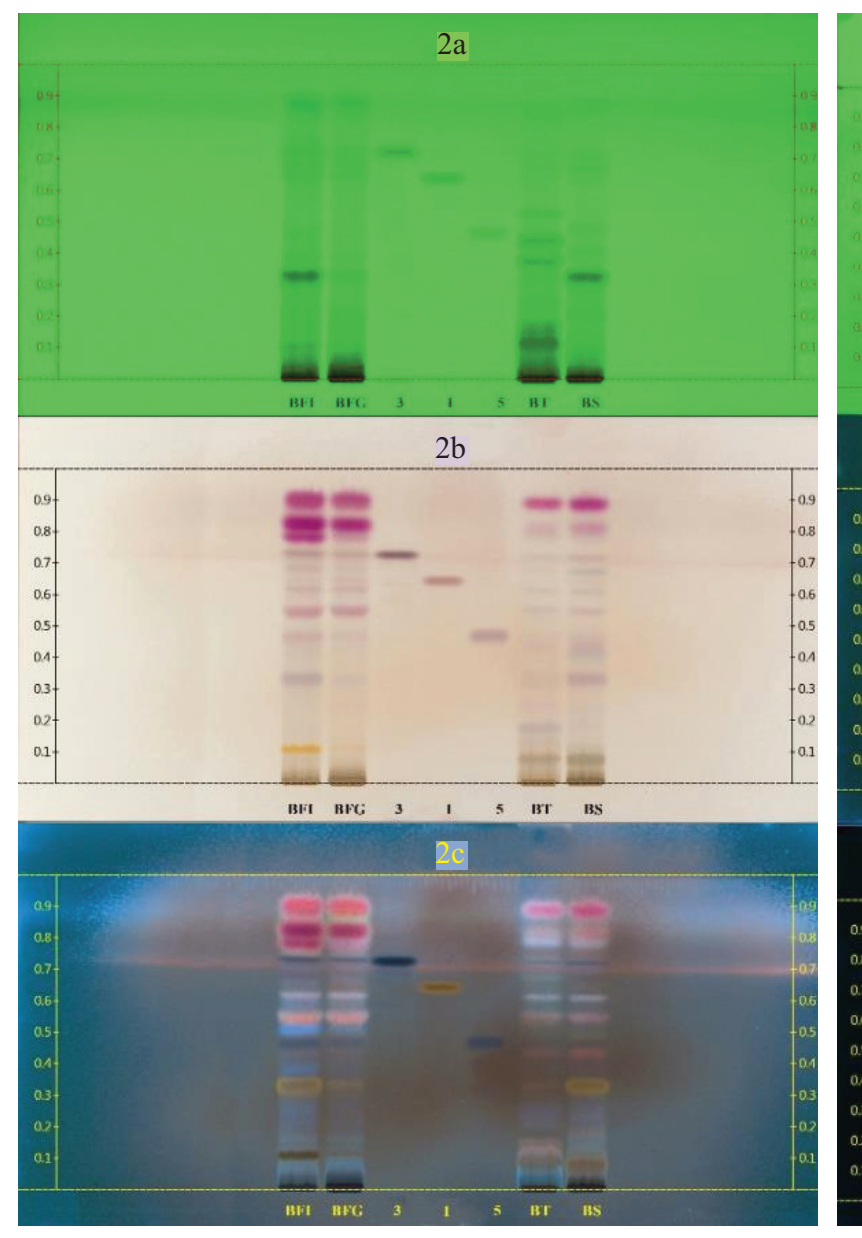

Jetstream ESI source. The separation of compounds was performed by using a reverse-phase HPLC Zorbax 300 SB-C ${ }_{18}$ column $(2.1 \mathrm{~mm} \times 150 \mathrm{~mm} ; 5 \mu \mathrm{m}$; Agilent Technologies) in a stepwise mobile phase gradient of $0.1 \%$ formic acid (solvent $\mathrm{A}$ ) and acetonitrile (solvent $\mathrm{B}$ ) at a flow rate of $0.3 \mathrm{~mL} / \mathrm{min}^{-1}$ with column temperature of $35{ }^{\circ} \mathrm{C}$. MS/MS detection was performed in negative ion mode in the $\mathrm{m} / \mathrm{z}$ interval of 50-1000 amu, targeted to $400 \mathrm{amu}$. The DAD was working at an interval of 200-600 $\mathrm{nm}$ and the absorbance of the eluate was continuously monitored at wavelengths of 250, 280, 330, 350, 370, and $590 \mathrm{~nm}$. Phenolic compounds were identified by retention time, mass to charge ratio $(\mathrm{m} / \mathrm{z})$, UV-vis spectra, and MS fragmentation patterns. Identification was confirmed with commercial standards of quinic acid, caffeic acid, vanillic acid, chlorogenic acid, catechin, kaempferol, myricetin, rutin, quercetin,
Fig. 2. Thin layer chromatogram developed with the eluent system (1) observed at $\lambda=254 \mathrm{~nm}$ (2a) before derivatization, white light (2b) and $\lambda=366 \mathrm{~nm}$ (2c) after derivatization with anisaldehyde-sulphuric acid reagent (2c).

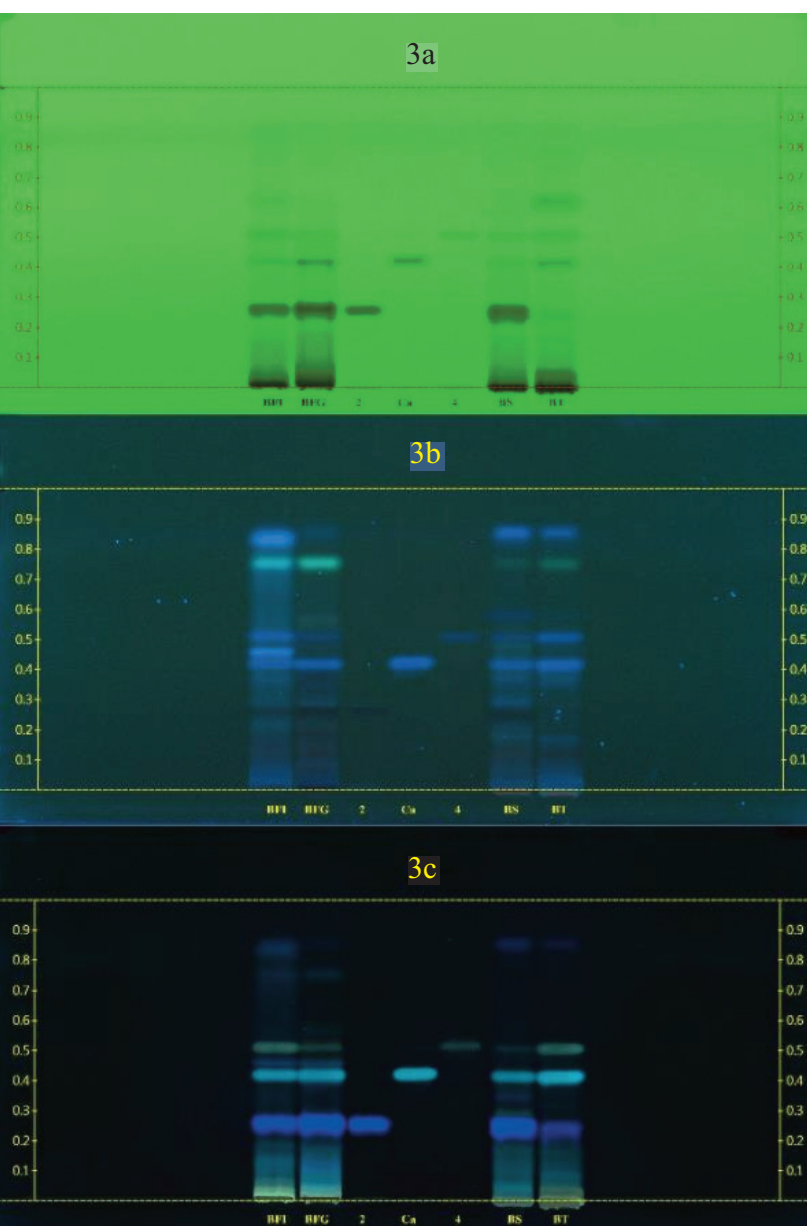

Fig. 3. Thin layer chromatogram developed with the eluent system (2) observed at $254 \mathrm{~nm}$ (3a) and ultra violet lamp $\lambda=366$ $\mathrm{nm}$ before ( $3 \mathrm{~b}$ ) and after ( $3 \mathrm{c}$ ) derivatization with NP/PEG reagent. 
quercetin rhamnoside, quercetin glucoside. External calibration curves were used for quantification of compounds either by UV-absorbance or extracted ion chromatogram (EIC) areas (Table 3). All the details were given in our previous study (Rusalepp et al., 2017).

\section{RESULTS AND DISCUSSION}

\subsection{Isolated compounds}

The ethyl acetate residue was purified with column chromatography to obtain five major compounds. Their chemical structures were identified by measuring and analysing NMR spectral data. These compounds were identified as isolariciresinol (1) (Eklund et al., 2002), gallic acid (2) (Eldahshan, 2011), pinoresinol (3) (Deyama et al., 1987), methyl caffeate (4) (Xiang et al., 2011) and epipinoresinol-4-O- $\beta$-D-glucopyranoside (5) (El-Domiaty et al., 2002), as illustrated in Fig. 4.

Isolariciresinol: ${ }^{1} \mathrm{H}$ NMR $\left(700 \mathrm{MHz}, 25{ }^{\circ} \mathrm{C}\right.$, acetone- $\left.d_{6}\right)$ : $7.38(\mathrm{~s}, 1 \mathrm{H}), 7.10(\mathrm{~s}, 1 \mathrm{H}), 6.79-6.73(\mathrm{~m}, 2 \mathrm{H}), 6.65(\mathrm{~s}, 1 \mathrm{H})$, $6.62(\mathrm{~d}, J=7.8 \mathrm{~Hz}, 1 \mathrm{H}), 6.19(\mathrm{~s}, 1 \mathrm{H}), 3.99-3.94(\mathrm{~m}, 1 \mathrm{H})$, $3.86-3.83(\mathrm{~m}, 1 \mathrm{H}), 3.82(\mathrm{~d}, J=11.0 \mathrm{~Hz}, 1 \mathrm{H}), 3.79$ (s, 3H), $3.77(\mathrm{~s}, 3 \mathrm{H}), 3.75-3.67(\mathrm{~m}, 3 \mathrm{H}), 3.43-3.37(\mathrm{~m}, 1 \mathrm{H}), 2.81$ $-2.71(\mathrm{~m}, 2 \mathrm{H}), 2.02-1.96(\mathrm{~m}, 1 \mathrm{H}), 1.84-1.78(\mathrm{~m}, 1 \mathrm{H})$; ${ }^{13} \mathrm{C}$ NMR $\left(176 \mathrm{MHz}, 25{ }^{\circ} \mathrm{C}\right.$, acetone- $\left.d_{6}\right): 148.3,146.5$, $145.8,145.3,138.5,134.0,128.5,122.9,116.9,115.6$, 113.6, 112.0, 65.9, 62.1, 56.3, 56.2, 48.3, 48.1, 40.5, 33.7.

Methyl caffeate: ${ }^{1} \mathrm{H}$ NMR $\left(700 \mathrm{MHz}, 25{ }^{\circ} \mathrm{C}\right.$, DMSO- $\left.d_{6}\right)$ : 9.37 (br s, 2H); 7.48 (d, $J=15.7 \mathrm{~Hz}, 1 \mathrm{H}), 7.05$ (d, $J=2.1$ $\mathrm{Hz}, 1 \mathrm{H}), 7.00(\mathrm{dd}, J=8.3,2.1 \mathrm{~Hz}, 1 \mathrm{H}), 6.76$ (d, $J=8.3$ $\mathrm{Hz}, 1 \mathrm{H}), 6.27$ (d, $J=16.2 \mathrm{~Hz}, 1 \mathrm{H}), 3.68$ (s, 3H); ${ }^{13} \mathrm{C} \mathrm{NMR}$ (176 MHz, $25^{\circ} \mathrm{C}$, DMSO- $\left.d_{6}\right): 167.0,148.4,145.6,145.2$, $125.5,121.4,115.7,114.8,113.7,51.2$.

Pinoresinol: ${ }^{1} \mathrm{H}$ NMR $\left(700 \mathrm{MHz}, 25{ }^{\circ} \mathrm{C}\right.$, DMSO- $\left.d_{6}\right): 8.89$ (s, 2H), 6.89 (d, $J=1.5 \mathrm{~Hz}, 2 \mathrm{H}), 6.77-6.71(\mathrm{~m}, 4 \mathrm{H}), 4.61$ $(\mathrm{d}, J=4.4 \mathrm{~Hz}, 2 \mathrm{H}), 4.14-4.10(\mathrm{~m}, 2 \mathrm{H}), 3.76(\mathrm{~s}, 6 \mathrm{H}), 3.72$ $(\mathrm{dd}, J=9.1,3.7 \mathrm{~Hz}, 2 \mathrm{H}), 3.05-3.01(\mathrm{~m}, 2 \mathrm{H}) ;{ }^{13} \mathrm{C} \mathrm{NMR}$ $\left(176 \mathrm{MHz}, 25^{\circ} \mathrm{C}, \mathrm{DMSO}-d_{6}\right): 147.5,145.9,132.2,118.6$, 115.1, 110.4, 85.1, 70.9, 55.6, 53.6.

Gallic acid: ${ }^{1} \mathrm{H}$ NMR $\left(700 \mathrm{MHz}, 25^{\circ} \mathrm{C}\right.$, DMSO- $\left.d_{6}\right): 12.12$ (br s, 1H), 9.14 (br s, 3H), 6.91 (s, 2H); ${ }^{13} \mathrm{C}$ NMR (176 $\left.\mathrm{MHz}, 25^{\circ} \mathrm{C}, \mathrm{DMSO}-d_{6}\right): 167.5,145.4,137.9,120.5,108.7$.

Epipinoresinol-4-O- $\beta$-D-glucopyranoside: ${ }^{1} \mathrm{H}$ NMR (700 $\left.\mathrm{MHz}, 25{ }^{\circ} \mathrm{C}, \mathrm{MeOD}\right): 7.15$ (d, $\left.J=8.2 \mathrm{~Hz}, 1 \mathrm{H}\right), 7.03$ (d, $J$ $=1.9 \mathrm{~Hz}, 1 \mathrm{H}), 6.98(\mathrm{~d}, J=1.6 \mathrm{~Hz}, 1 \mathrm{H}), 6.93(\mathrm{dd}, J=8.3$,

Table 3. Cytotoxicity of the isolated compounds

\begin{tabular}{|c|c|c|c|c|c|c|c|c|c|}
\hline \multirow[t]{3}{*}{ Samples } & \multirow{3}{*}{$\begin{array}{l}\text { Concentration } \\
\qquad(\mu \mathrm{g} / \mathrm{mL}\end{array}$} & \multicolumn{8}{|c|}{$\%$ Cell survival (CS\%) } \\
\hline & & \multicolumn{2}{|c|}{ MCF-7 } & \multicolumn{2}{|c|}{ A549 } & \multicolumn{2}{|c|}{ Hep3B } & \multicolumn{2}{|c|}{ PC3 } \\
\hline & & $\mathrm{CS} \%$ & $\pm \mathrm{SD}$ & $\mathrm{CS} \%$ & $\pm \mathrm{SD}$ & $\mathrm{CS} \%$ & $\pm \mathrm{SD}$ & $\mathrm{CS} \%$ & $\pm \mathrm{SD}$ \\
\hline \multirow[t]{2}{*}{1} & 30 & 70.26 & 1.09 & 74.71 & 1.33 & 77.89 & 1.80 & 76.35 & 2.59 \\
\hline & 100 & 59.04 & 2.20 & 69.61 & 2.41 & 57.97 & 1.48 & 63.15 & 1.28 \\
\hline \multirow[t]{2}{*}{2} & 30 & 71.13 & 2.09 & 68.25 & 3.31 & 74.46 & 2.08 & 66.22 & 2.54 \\
\hline & 100 & 35.82 & 2.70 & 50.45 & 2.14 & 53.13 & 2.33 & 43.30 & 1.42 \\
\hline \multirow[t]{2}{*}{3} & 30 & 69.51 & 2.43 & 63.63 & 2.39 & 80.25 & 0.27 & 66.13 & 0.08 \\
\hline & 100 & 62.40 & 1.47 & 55.96 & 2.22 & 57.23 & 1.65 & 61.36 & 0.25 \\
\hline \multirow[t]{2}{*}{4} & 30 & 87.32 & 1.40 & 71.53 & 1.02 & 73.72 & 1.40 & 82.80 & 2.28 \\
\hline & 100 & 72.55 & 0.96 & 64.04 & 1.21 & 61.81 & 0.52 & 74.78 & 2.41 \\
\hline \multirow[t]{2}{*}{5} & 30 & 69.91 & 2.17 & 60.66 & 4.25 & 78.47 & 1.15 & 74.41 & 1.99 \\
\hline & 100 & 63.59 & 2.13 & 62.80 & 8.64 & 63.73 & 2.39 & 66.50 & 1.37 \\
\hline \multirow[t]{2}{*}{ Camptothecin* } & $0.1 \mu \mathrm{g} / \mathrm{mL}$ & 54.46 & 2.37 & 50.05 & 2.10 & 71.10 & 1.23 & 53.81 & 0.14 \\
\hline & $10 \mu \mathrm{g} / \mathrm{mL}$ & 19.87 & 1.97 & 26.52 & 0.86 & 26.04 & 2.19 & 12.30 & 0.62 \\
\hline
\end{tabular}


<smiles>COc1cc(C2c3cc(O)c(O)cc3CC(CO)C2CO)ccc1O</smiles><smiles>COc1cc(C2OCC3C(c4ccc(C5OCC6C(c7ccc(O)c(OC)c7)OCC56)c(OC)c4)OCC23)ccc1O</smiles>

Fig. 4. Isolated compounds from the whole plant of Balanophora fungosa var. globosa: $\mathbf{1}$ - isolariciresinol, $\mathbf{2}$ - gallic acid, $\mathbf{3}$ - pinoresinol, 4 - methyl caffeate, 5 - epipinoresinol-4- $O$ - $\beta$-D-glucopyranoside.

$1.9 \mathrm{~Hz}, 1 \mathrm{H}), 6.82-6.77(\mathrm{~m}, 2 \mathrm{H}), 4.89(\mathrm{~d}, J=7.5 \mathrm{~Hz}, 1 \mathrm{H})$, $4.86(\mathrm{~d}, J=6.2 \mathrm{~Hz}, 1 \mathrm{H}), 4.48(\mathrm{~d}, J=6.9 \mathrm{~Hz}, 1 \mathrm{H}), 4.14(\mathrm{~d}$, $J=9.2 \mathrm{~Hz}, 1 \mathrm{H}), 3.88-3.84(\mathrm{~m}, 8 \mathrm{H}), 3.80(\mathrm{t}, J=8.7 \mathrm{~Hz}$, $1 \mathrm{H}), 3.71-3.67(\mathrm{~m}, 1 \mathrm{H}), 3.51-3.44(\mathrm{~m}, 2 \mathrm{H}), 3.42-3.36$ $(\mathrm{m}, 3 \mathrm{H}), 2.96-2.91(\mathrm{~m}, 1 \mathrm{H})$.

\subsection{Bioassay}

\subsubsection{NO production in LPS-stimulated RAW264.7 cells}

Isolariciresinol showed moderate inhibitory effect on $\mathrm{NO}$ production, whereas the inhibitory ability at concentration of $100 \mu \mathrm{g} / \mathrm{mL}$ was $56.02 \%$ (Table 2). Other separated compounds indicated lower activity (13.7-45.4\%). Cardamonin used as a positive control showed inhibitory activity of $30.3 \%$ and $79.8 \%$ at concentrations of $0.3 \mu \mathrm{M}$ and $3 \mu \mathrm{M}$, respectively. Isolariciresinol has been reported to modulate the production of inflammatory mediators through the attenuation of NF- $\mathrm{KB}$ transcription signalling (Chiou et al., 2011).

\subsubsection{Cytotoxic assays}

Gallic acid (GA) indicated moderate cytotoxicity against cancer cell lines MCF-7 (human breast carcinoma) and PC3 (human prostate gland carcinoma) at concentration of $100 \mu \mathrm{g} / \mathrm{mL}$ with the cell survival (CS\%) values of $35.8 \%$ and $43.3 \%$, respectively (Table 3). Gallic acid showed weak cytotoxicity against two other cancer cell lines A549 and Hep3B. The other studied compounds demonstrated weak cytotoxicity against all the four studied cell lines. Camptothecin used as a positive control showed significant cytotoxicity $(12.3-26.5 \%)$ at concentration of $10 \mu \mathrm{g} / \mathrm{mL}$ (Table 2). Relevant literature has revealed that GA is able to suppress cell growth and induce apoptosis in $\mathrm{PC} 3$ cells in prostate cancer in the range of IC50 concentrations ( $35 \mu \mathrm{M})$ (Saffari-Chaleshtori et al., 2017), while the half-maximal inhibitory concentration value for gallic acid against MCF-7 cells was 18 $\mu \mathrm{g} / \mathrm{mL}$ (Rezaei-Seresht et al., 2019).

\subsection{HPTLC and HPLC-MS/MS analyses}

\subsubsection{HPTLC analysis}

The chromatogram developed on the basis of the eluent system (1): chloroform-toluene-methanol-25\% aqueous ammonia (10:3:6:1) (v/v/v/v) (Fig. 2) showed that all three lignans $(\mathbf{1}, \mathbf{3}, \mathbf{5})$, isolated from $\mathrm{BFG}\left(\mathrm{R}_{f}=0.64,0.73\right.$ and 0.47 , respectively), had equivalent tracks in the chromatogram of BFI. There were nine equivalent tracks in the chromatograms of BFI and BFG, suggesting a similar chemical composition of these two taxa. There were five similar tracks in chromatograms of all the four samples (BFI, BFG, BT, BS) with $\mathrm{R}_{f}$ values of $0.33,0.54,0.62$, $0.73,0.82$, and 0.90 . Among them, the tracks with $\mathrm{R}_{f} 0.73$ could be attributed to pinoresinol $(3)\left(\mathrm{R}_{f}=0.73\right)$. However, isolariciresinol (1) $\left(\mathrm{R}_{f}=0.65\right)$ and epipinoresinol-4-O- $\beta$ D-glucopyranoside (5) $\left(\mathrm{R}_{f}=0.47\right)$ could not be detected in the chromatograms of BT and BS (Table 4). Also, the chromatograms of BT and BS possessed some equivalent tracks with $\mathrm{R}_{f}$ values of 0.08 and 0.43 , which could not be detected in the chromatograms of BFI and BFG (Table 4). Generally, the chromatograms developed on the basis of the eluent system (1) showed that pinoresinol (3) could be detected in the chromatograms of all the four samples while isolariciresinol (1) and epipinoresinol-4-O- $\beta-\mathrm{D}$ glucopyranoside (5) could be detected only in BT and BS. The chromatographic data also suggested that the two very 
Table 4. Evaluation of the HPTLC fingerprinting profile of the methanol extracts of Balanophora species, developed with the eluent system chloroform-toluene-methanol-25\% aqueous ammonia (10:3:6:1) and observed at white light after derivatization with anisaldehyde-sulphuric acid reagent

\begin{tabular}{|c|c|c|c|c|c|}
\hline \multirow[t]{2}{*}{$\mathrm{R}_{f}$ values } & \multicolumn{4}{|c|}{ Area percentage (\%) } & \multirow[t]{2}{*}{ Substances assigned } \\
\hline & BFI & $\mathrm{BFG}$ & BT & BS & \\
\hline $0.08 \pm 0.03$ & - & - & 8.24 & 6.93 & \\
\hline $0.11 \pm 0.02$ & 3.48 & 0.80 & - & - & \\
\hline $0.13 \pm 0.02$ & - & - & 0.63 & - & \\
\hline $0.18 \pm 0.03$ & - & - & - & 1.00 & \\
\hline $0.33 \pm 0.07$ & 6.79 & 4.01 & 9.85 & 12.14 & \\
\hline $0.43 \pm 0.02$ & - & - & 6.49 & 14.97 & \\
\hline $0.46 \pm 0.04$ & 5.12 & 3.28 & - & - & $\begin{array}{l}\text { Epipinoresinol-4- } O-\beta-\mathrm{D} \\
\text { glucopyranoside (5) }\end{array}$ \\
\hline $0.54 \pm 0.04$ & 6.73 & 8.00 & 4.04 & 3.06 & \\
\hline $0.62 \pm 0.04$ & 3.76 & 4.07 & 2.15 & 2.18 & \\
\hline $0.65 \pm 0.01$ & 1.49 & 2.73 & - & - & Isolariciresinol (1) \\
\hline $0.69 \pm 0.03$ & 4.04 & - & 1.47 & 4.32 & \\
\hline $0.73 \pm 0.03$ & 8.19 & 9.26 & 6.31 & 5.77 & Pinoresinol (3) \\
\hline $0.79 \pm 0.03$ & 12.26 & - & - & - & \\
\hline $0.82 \pm 0.03$ & 23.84 & 35.73 & 17.10 & 16.78 & \\
\hline $0.90 \pm 0.04$ & 23.52 & 30.23 & 37.18 & 31.56 & \\
\hline
\end{tabular}

close taxa of B. fungosa (BFI and BFG) have a similar chemical composition.

Furthermore, the chromatogram developed by using the eluent system (2): toluene-ethyl acetate-formic acid $(14: 10: 1)(\mathrm{v} / \mathrm{v} / \mathrm{v})($ Fig. 3) showed that the tracks equivalent to gallic acid (2) $\left(\mathrm{R}_{f}=0.25\right)$, methyl caffeate $(4)\left(\mathrm{R}_{f}=\right.$ $0.42)$ and caffeic acid $(\mathrm{Ca})\left(\mathrm{R}_{f}=0.51\right)$ could be detected in the chromatograms of all the four samples. However, the difference in the intensities of these tracks in the chromatogram could suggest the difference in the content of each compound in different samples. Also, both the chromatograms of BFG and BFI possessed a track with $\mathrm{R}_{f}$ value of 0.45 and blue inflorescence which could not be detected in the chromatograms of BT and BS.

\subsubsection{HPLC-MS/MS analysis}

Thirty-one compounds were identified in the methanolic extracts of the both taxa, whereas the major phenolic compounds were $O$-caffeoyl- $O$-galloyl-glucoside isomer I, caffeic acid glucoside, $O$-caffeoyl-di-galloyl- $\beta$-D-glucoside isomer $\mathrm{V}$, and 1-O-caffeoyl-3-O-galloyl-4,6-HHDP- $\beta$-Dglucoside (Table 5).

Generally, this is the first time that the chemical composition of $B$. fungosa var. globosa, a very rare plant in Vietnam, was investigated. The obtained chromatographic data suggested a similar chemical composition between $B$. fungosa var. globosa and its very close taxon $B$. fungosa subsp. indica, which in turn is a widely distributed species in Vietnam. What is more, it is the first time the HPTLC analyses of the four species $B$. fungosa subsp. indica, $B$. fungosa var. globosa, B. tobiracola and B. subcupularis were developed and evaluated. This could provide useful data for the identification and quality control of these Balanophora species. The moderate inhibitory effect of isolariciresinol on NO production may render antiinflammatory activity to extracts from Balanophora species. 
Table 5. Characterization of HPLC chromatograms of the methanolic extracts of BFG and BFI

\begin{tabular}{|c|c|c|c|}
\hline $\mathrm{tR}, \min$ & Compound & $\mathrm{M}-\mathrm{H}^{-}$ & Fragment ions \\
\hline 0.6 & Gallic acid glucoside & 331 & $313 ; 271 ; 211 ; 193 ; 169 ; 125$ \\
\hline 1.8 & Gallic acid & 169 & 125 \\
\hline 3.2 & Gallic acid glucoside & 331 & $271 ; 169$ \\
\hline $\begin{array}{c}5.6- \\
9.9\end{array}$ & Coniferin (several isomers) & 341 & $323 ; 223 ; 203 ; 179$ \\
\hline 7.6 & Caffeic acid glucoside & 341 & $323 ; 233 ; 203 ; 179 ; 135$ \\
\hline 11.3 & Caffeic acid glucoside & 341 & $179 ; 161 ; 135$ \\
\hline 12.6 & di-O-galloyl- $\beta$-D-glucoside isomer I & 483 & $423 ; 313 ; 271 ; 211 ; 193 ; 169$ \\
\hline 13.7 & di- $O$-galloyl- $\beta$-D-glucoside isomer II & 483 & $313 ; 271 ; 211 ; 193 ; 169$ \\
\hline 13.8 & p-coumaric acid glucoside & 325 & $307 ; 281 ; 195 ; 187 ; 163 ; 145 ; 119$ \\
\hline 16.4 & Derivative of coniferaldehyde & 385 & $177 ; 162 ; 149 ; 133$ \\
\hline 18.1 & $O$-caffeoyl- $O$-galloyl-glucoside isomer I & 493 & $331 ; 313 ; 271 ; 179 ; 169$ \\
\hline 20.1 & $O$-caffeoyl- $O$-galloyl-glucoside isomer II & 493 & $475 ; 433 ; 313 ; 271 ; 241 ; 169$ \\
\hline 20.1 & $O$-caffeoyl-di-galloyl- $\beta$-D-glucoside isomer I & 645 & $627 ; 585 ; 493 ; 423 ; 331 ; 271 ; 193$ \\
\hline 21.2 & $O$-caffeoyl- $O$-galloyl-glucoside isomer III & 493 & $331 ; 313 ; 271 ; 211 ; 169$ \\
\hline 21.9 & $O$-caffeoyl-di-galloyl- $\beta$-D-glucoside isomer II & 645 & $627 ; 493 ; 483 ; 465 ; 423 ; 301 ; 271$ \\
\hline 21.9 & Lariciresinol-glucoside & 521 & $491 ; 359 ; 329 ; 299 ; 161$ \\
\hline 23.1 & 1-O-caffeoyl-4,6-HHDP- $\beta$-D-glucoside & 643 & 301 \\
\hline 23.3 & Methyl caffeate & 193 & $178 ; 161 ; 134$ \\
\hline 23.5 & Lariciresinol & 359 & $344 ; 313 ; 241 ; 203 ; 189 ; 159 ; 109$ \\
\hline 24.6 & 1,3-di- $O$-caffeoyl- $\beta$-D-glucoside & 503 & $341 ; 323 ; 281 ; 233 ; 203 ; 179 ; 161$ \\
\hline 23.8 & $O$-caffeoyl-di-galloyl- $\beta$-D-glucoside isomer III & 645 & $475 ; 313$ \\
\hline 25.0 & Epipinoresinol-glucoside & 519 & $357 ; 311 ; 151$ \\
\hline 25.1 & $O$-caffeoyl-di-galloyl- $\beta$-D-glucoside isomer IV & 645 & $493 ; 483 ; 465 ; 423 ; 313 ; 271 ; 211$ \\
\hline 25.7 & 1-O-p-coumaryl-4,6-HHDP- $\beta$-D-glucoside & 627 & $463 ; 301$ \\
\hline 26.1 & $\begin{array}{l}\text { 1-O-caffeoyl-3-O-galloyl-4,6-HHDP- } \beta \text {-D- } \\
\text { glucoside }\end{array}$ & 795 & $751 ; 589 ; 493 ; 419 ; 301 ; 275 ; 249$ \\
\hline 26.4 & $O$-caffeoyl-di-galloyl- $\beta$-D-glucoside isomer $\mathrm{V}$ & 645 & $493 ; 483 ; 465 ; 423 ; 313 ; 271$ \\
\hline
\end{tabular}


Table 5. Continued

\begin{tabular}{l|l|c|c}
\hline tR, min & \multicolumn{1}{c|}{ Compound } & M-H & Fragment ions \\
\hline 27.3 & Isolariciresinol & 359 & $329 ; 299 ; 256 ; 189 ; 159$ \\
27.4 & 2-O-caffeoyl-1- $p$-coumaryl- $\beta$-D-glucoside & 487 & $469 ; 341 ; 323 ; 233 ; 203 ; 179 ; 161 ; 135$ \\
28.8 & 6-O-caffeoyl-1,3,4-tri- $O$-galloyl- $\beta$-D-glucoside & 797 & $645 ; 627 ; 475 ; 295$ \\
29.2 & 1,3-di- $O$-caffeoyl-4,6-HHDP- $\beta$-D-glucoside & 805 & $643 ; 503 ; 301 ; 275$ \\
31.2 & Pinoresinol & 357 & $342 ; 327 ; 311 ; 151 ; 136$
\end{tabular}

\section{CONCLUSIONS}

Phytochemical studies of Vietnamese B. fungosa var. globosa led to the isolation of the five earlier known compounds named isolariciresinol (1), gallic acid (2), pinoresinol (3), methyl caffeate (4) and epipinoresinol-4$O$ - $\beta$-D-glucopyranoside (5). Isolariciresinol indicated moderate inhibitory effect on NO production, while gallic acid at the concentration of $100 \mu \mathrm{g} / \mathrm{mL}$ demonstrated moderate cytotoxicity against two cancer cell lines MCF-7 and PC3. Gallic acid (2), pinoresinol (3), methyl caffeate (4) and caffeic acid could be detected in all the chromatograms of the four samples by using the HPTLC analyses. The chromatographic data of the methanol extracts of BFG and BFI showed high similarity in the chemical composition of these two taxa. The HPLC analyses led to the identification of thirty-one compounds in the methanolic extracts of the both taxa with $O$-caffeoyl$O$-galloyl-glucoside isomer I, caffeic acid glucoside, $O$-caffeoyl-di-galloyl- $\beta$-D-glucoside isomer $\mathrm{V}$, and 1-O-caffeoyl-3-O-galloyl-4,6-HHDP- $\beta$-D-glucoside being the main phenolic compounds.

\section{ACKNOWLEDGEMENTS}

This work was supported by Vietnam Academy of Science and Technology (VAST) through the project VAST.CTG.04/1617. The publication costs of this article were covered by the Estonian Academy of Sciences.

\section{REFERENCES}

Ban, N. T. 2005. List of Plants in Vietnam, 3rd vol. Agriculture Publishing House, Hanoi (in Vietnamese).

Bui, H. T., Nguyen, X. N., Pham, H. Y., Tran, H. Q., Nguyen, T.C., Do, T. T., et al. 2019. Three new muurolane-type sesquiterpene glycosides from the whole plants of Balanophora fungosa subsp. indica. Nat. Prod. Res., https://doi.org/10. 1080/14786419.2019.1602831
Chiou, W. F., Shen, C. C., and Lin, L. C. 2011. Antiinflammatory principles from Balanophora laxiflora. $J$. Food Drug. Anal., 19(4), 502-508.

Dai, Z., Wang, G. L., Wang, F., Ma, S. C., and Liu, R. C. 2005. Chemical constituents from Balanophora simaoensis (I). Chin. Tradit. Herb. Drugs, 36(6), 830-831.

Dai, Z., Wang, G. L., Liu, Y., Zhang, J., and Lin, R. C. 2005. The chemical constituents study of Balanophora simaoensis. Chin. J. Chin. Mat. Med., 30(14), 1131-1132.

Dat, N. T., Binh, P. T. X., Quynh, L. T. P., Huong, H. T., and Minh, C. V. 2012. Sanggenon $C$ and O inhibit NO production, iNOS expression and NF- $\kappa \mathrm{B}$ activation in LPSinduced RAW264.7 cells. Immunopharmacol. Immunotoxicol., 34(1), 84-88.

Deyama, T., Ikawa, T., Kitagawa, S., and Nishibe, S. 1987. The constituents of Eucommia ulmoides Oliv. V. Isolation of dihydroxydehydrodiconiferyl alcohol isomers and phenolic compounds. Chem. Pharm. Bull., 35(5), 1785-1789.

Eklund, P., Sillanpää, R., and Sjöholm, R. 2002. Synthetic transformation of hydroxymatairesinol from Norway spruce (Picea abies) to 7-hydroxysecoisolariciresinol, (+)-lariciresinol and (+)-cyclolariciresinol. J. Chem. Soc., Perkin Trans. 1, 2(16), 1906-1910.

El-Domiaty, M. M., El-Shafae, A. M., Abdel-Aal, M. M., and Abou-Hashem, M., M. 2002. The first report on the occurrence of furofuranoid lignan glucosides in Acanthaceae. Pharm. Biol., 40(2), 96-102.

Eldahshan, O. A. 2011. Isolation and structure elucidation of phenolic compounds of carob leaves grown in Egypt. Curr. Res. J. Biol. Sci., 3(1), 52-55.

Fang, L., He, T.-T., Wang, X., and Zhou, J. 2018. Isolation and purification of galloyl, caffeoyl, and hexahydroxydiphenoyl esters of glucoses from Balanophora simaoensis by highspeed countercurrent chromatography and their antioxidant activities in vitro. Molecules, 23(8), 2027.

Hansen, B. 1972. The genus Balanophora J.R. \& G. Forster - A taxonomic Monograph. Dansk Bot. Ark. 28, Copenhagen.

Hou, Q.-Y., Dai, Z., Cheng, X.-L., and Lin R.-C. 2009. Comparative study on chemical components of 5 species of Balanophora. Chin. J. Pharm. Anal., 29(5), 697-701.

Ito, K., Itoigawa, M., Haruna, M., Murata, H., and Furukawa, H. 1980. Dihydrochalcones from Balanophora tobiracola. Phytochemistry, 19(3), 476-477.

Panthama, N., Kanokmedhakul, S., and Kanokmedhakul, K. 2009. Galloyl and hexahydroxydiphenoyl esters of phenylpropanoid glucosides, phenylpropanoids and phenyl- 
propanoid glucosides from rhizome of Balanophora fungosa. Chem. Pharm. Bull., 57(12), 1352-1355.

Rezaei-Seresht, H., Cheshomi, H., Fakanji, F., MovahediMotlagh, F., Hashemian, M., and Mireskandari, E. 2019. Cytotoxic activity of caffeic acid and gallic acid against MCF-7 human breast cancer cells: An in silico and in vitro study. Avicenna J. Phytomedicine, 9(6), 574-586.

Rusalepp, L., Raal, A., Püssa, T., and Mäeorg, U. 2017. Comparison of chemical composition of Hypericum perforatum and H. maculatum in Estonia. Biochem. Syst. Ecol., 73,41-46. https://doi.org/10.1016/j.bse.2017.06.004

Saffari-Chaleshtori, J., Heidari-Sureshjani, E., Moradi, F., Jazi, H. M., and Heidarian, E. 2017. The study of apoptosisinducing effects of three pre-apoptotic factors by gallic acid, using simulation analysis and the comet assay technique on the prostatic cancer cell line PC3. Malays. J. Med. Sci., 24(4), 18-29.

Scudiere, D. A., Shoemaker, R. H., Paull, K. D., Monks, A., Tierney, S., Nofziger, T. H., et al. 1988. Evaluation of a soluble tetrazolium/formazan assay for cell growth and drug sensitivity in culture using human and other tumor cell lines. Cancer Res., 48(17), 4827-4833.

Tanaka, T., Uehara, R., Nishida, K., and Kouno, I. 2005. Galloyl, caffeoyl and hexahydroxydiphenoyl esters of dihy- drochalcone glucosides from Balanophora tobiracola. Phytochemistry, 66(6), 675-681.

Tung, N. T., Quan N. V., Anh. N. P., Phuong. N. V., and Hung, N. Q. 2019. Preliminary phytochemical evaluation and in vitro xanthine oxidase inhibitory activity of Balanophora subcupularis P. C. Tam and Balanophora tobiracola Makino (Balanophoraceae). Trop. J. Nat. Prod. Res., 3(1), 6-9. https://doi.org/10.26538/tjnpr/v3i1.2

Vo, V. C. 2012. Dictionary of Vietnamese medicinal plants (New edition), vol. 1. Medical Publishing House, Hanoi (in Vietnamese).

Wang, X., Liu, Z., Qiao, W., Cheng, R., Liu, B., and She, G. 2012. Phytochemicals and biological studies of plants from the genus Balanophora. Chem. Cent. J., 6(1), 79. https://doi.org/10.1186/1752-153X-6-79

Xiang, M., Su, H., Hu, J., and Yan, Y. 2011. Isolation, identification and determination of methyl caffeate, ethyl caffeate and other phenolic compounds from Polygonum amplexicaule var. sinense. J. Med. Plants Res., 5(9),1685-1691.

Zhou, J., Du, S.-Y., Fang, Z.-Y., and Zeng, Z. 2019. New butenolides with anti-inflammatory activity from Balanophora fungosa. Nat. Prod. Res. https://doi.org/10.1080/14786419. 2019.1645663

\title{
Vietnamis kasvava Balanophora fungosa varietas globosa koostisained ja nende bioloogiline aktiivsus ning võrdlev kromatograafiline analüüs mõnede perekonna Balanophora J.R. \& G. Forst liikidega
}

\author{
Nguyen Thanh Tung, Nguyen Quang Hung, Nguyen Thi Luyen, Nguyen Tien Dat, Tõnu Püssa, \\ Linda Rusalepp, Mihkel Ilisson ja Ain Raal
}

Vietnamis kasvava taime Balanophora fungosa varietas globosa keemilist koostist ja bioloogilist aktiivsust uuriti selles töös esmakordselt. Samuti võrreldi mõnede Balanophora perekonna liikide keemilist koostist. Fenoolsed ühendid isolaritsiresinool (1), gallushape (2), pinoresinool (3), metüülkafeaat (4) ja epipinoresinool-4-O- $\beta$-D-glukopüranosiid (5) isoleeriti ning identifitseeriti NMR-analüüsi tulemusel Vietnamist kogutud B. fungosa varietas globosa droogiproovi põhjal. Isoleeritud koostisainete mõned toimed, nagu NO produktsiooni inhibeeriv ja rakutoksiline efekt, tehti kindlaks in vitro. Töötati välja kromatograafilised meetodid $B$. fungosa varietas globosa ja sellele väga lähedase taksoni $B$. fungosa subsp. indica (Arn.) B. Hansen, aga ka Vietnamist hiljuti avastatud kahe uue liigi Balanophora tobiracola Makino ja Balanophora subcupularis P.C. Tam (BS) omavaheliseks eristamiseks. Isoleeritud komponentidest näitas isolaritsiresinool keskmise tasemega NO produktsioon I inhibeerivat efekti $(\mathrm{I} \%=56,02$ kontsentratsioonil $100 \mu \mathrm{g} / \mathrm{mL})$, samas oli gallushappel kontsentratsiooni $100 \mu \mathrm{g} / \mathrm{mL}$ korral keskmine rakutoksiline aktiivsus inimese rinnakartsinoomi rakkudesse (MCF-7) ja eesnäärmekartsinoomi rakkudesse (PC3). HPTLC-analüüs näitas sarnasust $B$. fungosa varietas globosa ja $B$. fungosa subsp. indica keemilise koostise vahel, mis aga oli erinev $B$. tobiracola ja $B$. subcupularis'e fütokeemilise profiili puhul. Kahes sarnase koostisega taksonis identifitseeriti HPLC-MS/MS-meetodil 31 fenoolset ühendit, millest peamised on $O$-kafeoüül-O-galloüülglükosiid I, kohvhappeglükosiid, $O$-kafeoüüldigalloüül- $\beta$-D-glükosiid V ja 1-O-kafeoüül-3-Ogalloüül-4,6-HHDP- $\beta$-D-glükosiid. 